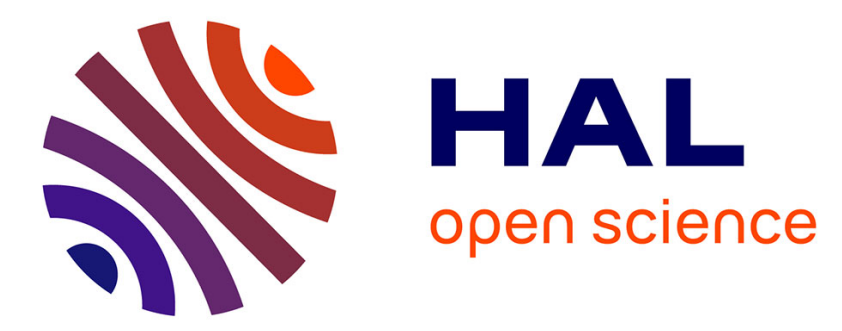

\title{
Asian cities in the global maritime network since the late nineteenth century
}

César Ducruet

\section{To cite this version:}

César Ducruet. Asian cities in the global maritime network since the late nineteenth century. Asian cities: from colonial to global, Apr 2013, Leiden, Netherlands. halshs-01069369

\section{HAL Id: halshs-01069369 \\ https://shs.hal.science/halshs-01069369}

Submitted on 29 Sep 2014

HAL is a multi-disciplinary open access archive for the deposit and dissemination of scientific research documents, whether they are published or not. The documents may come from teaching and research institutions in France or abroad, or from public or private research centers.
L'archive ouverte pluridisciplinaire HAL, est destinée au dépôt et à la diffusion de documents scientifiques de niveau recherche, publiés ou non, émanant des établissements d'enseignement et de recherche français ou étrangers, des laboratoires publics ou privés. 


\title{
Asian cities in the global maritime network since the late
}

\section{nineteenth century}

\author{
César DUCRUET \\ French National Centre for Scientific Research (CNRS) \\ UMR 8504 Géographie-Cités \\ 13 rue du Four, F-75006 Paris (France) \\ cdu@parisgeo.cnrs.fr
}

This work is dedicated to the memory of Prof. W. Rhoads Murphey III

Text version of the oral communication at "Asian cities: from colonial to global", International Institute for Asian Studies \& TU Delft Seminar, Leiden, The Netherlands, 2325 April 2013.

\section{Introduction}

One of the most striking features of contemporary Asia is the dominant concentration of population and economic activities along its shores, with a limited inland penetration of hinterlands (Arasaratnam, 1992). Many scholars have already acknowledged the importance of port activities throughout Asian history (McGee, 1967; Basu, 1985; Murphey, 1989; Broeze, 1997; Gipouloux, 2009), Asian cities being best understood in their form and function as "brides of the sea" (Broeze, 1989). Despite many physical difficulties inherent to rapid urban and port growth (Ness and Tanigawa, 1992), maritime networks remain more than ever essential to the development of Asian cities and their host nations (Taillard, 2004). Port traffics have long been closely tied to their adjacent urban economies although like in other 
regions, Asian port cities have developed a preference for other, more lucrative transport functions such as airlines (Okuno, 2000) and value-added logistics (Cheung et al., 2003; Wang and Chen, 2010). Nevertheless, certain aspects such as urban morphology have remained rather stable over time, as in the case of main Indian cities (Kosambi and Brush, 1988).

While such aspects have been abundantly documented through case studies of particular places at specific time periods, this chapter innovates by mapping for the first time the changing distribution of port activities in Asia over the last 120 years. A snapshot of maritime activity every 40 years or so was chosen to best reflect major evolutions in the port hierarchy and the functions of Asian cities. How path-dependent have been port activities in Asia since the late nineteenth century? How can a study of maritime flows reveal some of the factors explaining the emergence of the current port city hierarchy? In this chapter, Asia is defined by its most extended definition ranging geographically from Greece to Siberia, but excluding Oceania. Whenever possible, reference is made to existing works on Asian port cities but without pretending to be exhaustive. One way to complement historical research has been to cover a number of papers written by geographers about Asian ports since the 1950s based on a review by $\mathrm{Ng}$ and Ducruet $(2014)^{1}$ on port geography in general. All in all, the main goal of this research is to provide a solid comparative overview serving as a reference for more detailed studies.

\section{Methodology and preliminary results}

An untapped resource was used in this study to measure the level and nature of port activities worldwide, namely merchant vessel movements published by Lloyd's List, the world's leader

\footnotetext{
${ }^{1}$ See Appendix 1 for an overview of port geography papers about Asian port cities consulted as secondary sources in this chapter
} 
in maritime insurance and intelligence, on a daily or weekly basis. Such publications have never been used in a systematic manner but as a secondary source to identify specific vessels for detailed uses. This is rather surprising because it contains most of world trade activities through a very detailed description of vessels and their circulation, thereby allowing an analysis of shipping routes and port hierarchies as well as traffic concentration levels. Such documents provide new possibilities to understand, among other possible research fields, the precise position of Asian port cities in light of global maritime flows. The number of vessels, vessel calls was calculated in order to establish a ranking of Asian port cities according to their level of overall maritime and port activity.

The study period chosen in this chapter starts in 1890 and ends in 2008. This choice is partly explained by data availability but mostly by the fact that Lloyd's List started to include information from its direct competitors since 1890 onwards, i.e. vessel movement information from fleets insured by other companies, such as Nordske Veritas (Denmark) and Bureau Veritas (Belgium-France), but also Russian and Japanese fleets. This makes the spatial coverage of the analysis more relevant and complete than in the pre-1890 period when only the movements of British vessels were reported. More concretely, Lloyd's List reports in its Shipping Index the origin-destination of vessel voyages among ports of the world, including the dates of departures and arrivals, the type of vessels (e.g. steamer, tanker, containership) as well as their flag, registry, and tonnage capacity. Not all such information is used in this chapter, which focuses dominantly on counting the number of port calls per continent, region, and port city. A snapshot of global maritime activity has thus been extracted manually from paper sources in $1890,1925,1951,1960,1965,1970,1975,1980,1985,1990,1995,2000$, and 2008, around the months of April-May, i.e. one publication only among the 52 weekly publications each year. Figure 1 provides an example of such records for sailing vessels in 
1890: each vessel has one voyage reported between two or more ports, depending on the mention or not of intermediary calls along the route. The method has been to calculate the sum of movements for each port on the level of the global maritime network formed by the links among the ports (see also Ducruet, 2013).

[Insert Figure 1 about here]

Lastly and although it is strictly impossible to systematically confront the global data from Lloyd's to more local information on port activities due to obvious constraints, a focus on China is proposed in Figure 2. The data collected by Wang and Ducruet (2013) about Chinese port traffics over the 1868-2009 period $^{2}$ confirms the accuracy of the global source, despite, for instance, the non-inclusion of river traffics by Lloyd's, which is more specialized in tracking ocean-going vessels embarked on international trades. For China's totals, the powerlaw relation between tonnage (local) and vessel calls (global) accounts for no less than 95\%, while for Shanghai, it amounts to $92 \%$ using the same statistical method. It is also satisfactory to observe identical traffic variations in times of drastic political changes, as seen with the sharp decline of all traffics between 1925 and 1951. The rest of the evolution is more linear for tonnage and more fluctuating for vessel calls, but this is probably due to the fact that vessel calls do not take into account the size of vessels, in terms of their carrying capacity. Nevertheless, such an exercise, especially based on such a complex case like China, demonstrates the accuracy of Lloyd's information and its ability to translate not only global but also local dynamics, thereby motivating its application to the rest of Asia.

\footnotetext{
${ }^{2}$ Chinese data consists in port traffics provided by the Chinese Customs measured in Hong Kong Taels for the period 1868-1938), and by the Ministry of Transportation measured in metric tons for the period 1932-2009. The two time series were adjusted based on one single unit, the metric ton, although the first does only report international traffics, thus excluding domestic activities (Wang and Ducruet, 2013).
} 
[Insert Figure 2 about here]

It is a fact that Asia as a whole had concentrated a growing proportion of global port activity, from about $10 \%$ in 1890 to nearly $45 \%$ in 2008 . This evolution is by no means illustrative of the well-known global shift of production and manufacturing that occurred since the 1960s, notably promoting East Asia as one of the three major economic poles of the world economy. As seen in Figure 3, the share of Asia as a whole has grown at the expense of the two other main economic poles, namely Europe and North America, while other regions have seen their relative weight rather stagnant over the period. One notable exception is the initial and overwhelming importance of Latin America, mostly backed at the time by the economic boom of Argentina around Buenos Aires. In fact, Asia's growth has been rapid in the first phase in a context of increased colonial interests, then stabilized in the 1970s and 1980s following the independence of former colonies, and went through a rapid growth again from the 1990s onwards, based on rapid port modernization and the "China effect".

[Insert Figure 3 about here]

Internal trends are more visible in Figure 4, where one can observe very huge traffic shifts across Asia over time. Northeast Asia has become Asia's largest concentration of port activity as it comprises Japan, China, and three of the four so-called "Asian Dragons" (South Korea, Taiwan, and Hong Kong) where port growth has been the fastest. At the start of the study period, the Indian subcontinent was by far the largest port region, but its share rapidly shrunk up to the 1970 s, leaning towards a mere $10 \%$ nowadays. This evolution has a lot to do with the demise of the British Empire and, of course, the rapid industrialization of Japan, largely dependent upon maritime trade. Southeast Asia occupies the second rank nowadays, which 
was also true in 1890 , but it is only from the 1990s that it regained this position. One main reason has been the reinforced connectivity of the Singapore hub to cope with the rise of the so-called "Asian Tigers" in that region. The fast growth of port activity in the Middle East in the early period is largely due to the boom of oil trade and shipping. East and South Asia altogether occupy no less than $70 \%$ of Asia's total port activity nowadays. The role of individual port cities is explored in the next section.

[Insert Figure 4 about here]

\section{Changing port hierarchies of Asian cities}

\subsection{Overall traffic distribution}

Asian ports have become organized around a trunk line or corridor along which major hubs concentrate and redistribute cargo flows to/from secondary ports (Ducruet et al., 2011). Recent structures are, of course, inherited from the past and notably colonial times when EastWest routes were based on strategically located comptoirs for entrepot trade established by European powers (Murphey, 1963) and even on earlier trade patterns taking place prior colonialism (Gipouloux, 2009). Figure 5 serves to situate the main port cities of Asia and their changing level of activity from one period to the other.

[Insert Figure 5 about here]

The most active cities in 1890 belong to European empires (e.g. India, Hong Kong, Singapore, Myanmar, Indonesia, Macau, Philippines) with Calcutta being the largest port at the time (Dutt, 1971; Tan, 2007) but also Japan, China, and the Black Sea. Overall, Asia has a high proportion of steamer traffic compared with the rest of the world outside the North 
Atlantic in the late nineteenth century (Ducruet, 2012). Besides the stability of the port system in the second period, certain cities have witnessed tremendous growth, as reflected by Yokohama and Kobe in a context of industrial and colonial expansion since the Meiji era, with direct impacts on Dalian in China (Todd and Zhang, 1993). Other cases such as Karachi in Pakistan (Maxwell, 1957; De Nie, 1960), Mumbai, Galatz, Constantza, and Piraeus better depict the reinforced importance of the Europe-Asia link through the Suez Canal built in 1869. In comparison, Hong Kong and Shanghai have seen their activity stabilizing or even declining due to political instabilities in mainland China. Yet, Shanghai remains China's main gateway with the outside world due to its sea-river connection through the Yangtze (Reischauer, 1940; Wiens, 1955; Tang, 2009), far beyond Tianjin for instance (Hitch, 1935). In the early 1960s, Japan keeps its prominence as five of the top twenty cities are Japanese (Hanrath, 1960). There is a rapid growth of Hong Kong (Boxer, 1962; Dwyer, 1963) and Singapore as the new Asian Tigers promoting export-led growth through free-zone development as well as elsewhere in Asia (Robinson, 1984), compared with the relative decline of Indian ports where new ports have developed outside traditional port cities for the bulk handling of raw materials (Van Suylichem, 1968; Kidwai, 1989). Another specificity of the 1960s is the fast growth of Gulf ports (Hugues, 1979; Walker, 1989; Jacobs and Hall, 2007) of which Dubai and specialized oil ports (e.g. Mena al Ahmadi, Ras Tanura), transit hubs (Aden), but also of Black Sea ports such as Odessa in a context of Soviet control (Krug, 1964). Aden was still at the time part of the British Empire with facilities dedicated to British Petroleum, but also acting as an interregional hub port for mail. Other Asian ports received far less attention from geographers except from specific papers on Keelung (Chen, 1957), Borneo (Lee, 1962), Cebu (Uernstedt, 1966), and Malaysia (Ward, 1961, 1966). 
The last period confirms the overwhelming dominance of the Asian Tigers and Japan concentrating twelve of the top twenty ports in 2008 , followed by other major ports in China (Shanghai), East Mediterranean and Black Sea (Alexandria, Piraeus, Constantza), Southeast Asia (Port Klang, Jakarta), and the Middle East (Fujairah, Jebel Ali). Across the entire study period, only Japan, Hong Kong, Singapore, and Jakarta have remained among the top twenty Asian ports notwithstanding certain fluctuations in their rank order. This relative success is well reflected by a voluminous literature on the evolution of containerization in such Asian global port cities (Robinson and Chu, 1978; Bristow et al., 1995; Airriess, 2001a) but also urban and regional issues in port development (Todd and Hsueh, 1990; Chang et al., 2004; Lee and Ducruet, 2009) as well as competition and technological diffusion in port systems (Airriess, 1989, 1991; Slack and Wang, 2002; Song, 2002). South Asian ports have clearly lost their initial importance in recent times (India, Pakistan, Sri Lanka, Myanmar) compared with the rapid growth of Korean and Taiwanese ports such as Busan (Frémont and Ducruet, 2005), Incheon (Ducruet et al., 2012), and Kaohsiung (Todd, 1993; Haynes et al., 1997). Chinese ports received attention only recently after a period of maturation in the container business, on the level of the whole country (Todd, 1997; Wang and Ng, 2011; Wang and Ducruet, 2013), large regions such as the Pearl River Delta (Wang and Slack, 2000), or individual cities and corridors (Todd, 1994; Wang and Olivier, 2006; Wang and Ducruet, 2012), except from very few case studies in the past (see Tregear, 1954). Other abundant works have been published in more transport-oriented journals dealing with aspects of port governance, operation, and management, thus reaching beyond the scope of this chapter despite their relevance. Elsewhere in Asia, Piraeus also had a relatively stable position among major ports, while the Black Sea was always represented but by different ports over time.

\subsection{Individual port trajectories}


Mapping the more detailed evolution of individual Asian port cities is addressed here based on a selection of the three largest ports of each sub-region of Asia, in terms of their average number of vessel calls all along the period (Figure 6). Hong Kong and Singapore are kept apart for the sake of comparability as their transshipment hub activity gives them a too high number of calls to be placed in the same figure with other Asian ports. The most striking fact is the vast heterogeneity of trajectories among Asian ports, even within the same sub-region. Still, in Japan, the top ports went through growth and decline phases rather accordingly, while Nagoya could enjoy a more stable profile probably due to the prolonged vitality of its automobile industry, much relying on the port for coastal and overseas trade. The relative decline of Japanese ports in recent decades is explained by several factors: an environmentfriendly transport policy in favor of smaller ports and coastal shipping to prevent further expansion of already gigantic ports, the shift of transshipment activities to South Korea and notably Busan, and an overall reduction of demand in an ageing country where cargo value takes over cargo volume in the priorities. In the rest of Northeast Asia, Busan and Kaohsiung show a close trajectory; with an earlier take-off of Kaohsiung notably since the development of its free-trade zone in 1966. Shanghai has a distinct profile although it also has grown fast in recent decades and, interestingly, it is only in the 1990s that its number of calls had been lesser than Busan. From 2008 however, Shanghai has become the world's largest port in terms of tonnage, and the second in Asia after Singapore for the number of vessel calls. As already investigated earlier, the rise of traffic volumes did not necessarily mean a shift of centrality towards Shanghai from other established hub ports, which, at the contrary, reinforced their transshipment activities during that period, for technologiczal but also geopolitical reasons of logistical and information control, and also due to the fact that China still nowadays does not offer a transparent business environment to foreign investors, of which global shipping lines and terminal operators (Ducruet et al., 2010). 
[Insert Figure 6 about here]

Between Hong Kong and Singapore, the huge difference observed by the number of vessel calls overestimates Singapore's true importance in the region. The simple fact that more than $80 \%$ of Singapore's total port activity is dedicated to transit trade (transshipment) largely explains those numbers, bearing in mind that most of containers are counted twice during the transit over Singapore. Also, such a transshipment activity has the direct effect of increasing the call frequency of smaller vessels (feeder vessels) that redistribute the cargo from larger (mother) vessels within and between regions. Another differentiating factor is the lack of landside access from Singapore to the continent, whereas for Hong Kong, its gateway function towards Mainland China has always been a decisive aspect of its activity, even prior China's official opening to the world in the late 1970s. In the rest of Southeast Asia, Manila is rather stagnating over the period, while Bangkok went through a rapid decline after reaching a peak of activity in the early 1990s. Like in other South Asian cities, and as seen in Figure 6 with other cases such as Calcutta, Mumbai and Karachi, modern port activities have been shifted outside the original urban core. Yet, such spatial dislocations of port areas to cope with lack of space and congestion in rapidly growing cities are not counted here because the unit of analysis if the compact port area, not the larger metropolitan city or agglomeration. New ports such as Bin Qasim for Karachi, Haldia for Calcutta, Neva Sheva for Mumbai, Laem Chabang for Bangkok are clear example of renewed port functions outside traditional Asian port cities. Further research on those shall, perhaps, reintegrate the activity of new ports in the data analysis in order not to underestimate the current level of their total activity. Still, local factors and planning problems remain secondary compared with the wider geopolitical shifts that occurred, for instance, in India when the British Empire was dismantled, with direct effects on 
port activity in Mumbai and Calcutta, but also Karachi and Yangon (see also Figure 5). Competition for oil resources extraction and shipping better explains the decline of Ras Tanura and Mina al Ahmadi in the Middle East, but again, the activity of Dubai (Port Rashid) is by no means underestimated given the rapid growth of the recently developed Jebel Ali container port, which has become the main hub of the region in recent years.

\section{Conclusion}

This chapter has tackled a difficult exercise that was to map and analyze the changing spatial pattern of the Asian port system since the late nineteenth century. This posed a number of conceptual and methodological challenges, from the definition of "Asia" to the technical feasibility of measuring port activity across such a large land mass and over such a long period of time. Due to the existence of a largely untapped resource, namely vessel movement information published by the maritime insurer Lloyd's List, the goal has been achieved and the main results provide novel evidence about one of the major economic functions exerted by Asian cities, "brides of the sea" (Broeze, 1989). Although such a large-scale approach has blurred the local situations and dynamics, it made possible to evaluate and compare the unevenness of port activity throughout the Asian port system at selected key periods based on harmonized measures. The main lesson to be drawn from this study is, perhaps, the confirmation of Asia's early and reinforced importance in global trade during the contemporary era. The current pattern of port activity has witnessed important shifts in the region, but it still rests on inherited patterns that exhibit strong path-dependency. Yet, "colonial Asia" remains very different from "global Asia" in many ways. Like other main economic poles of the world system, it faces important challenges of port-city planning due to the unprecedented levels of traffic concentration at its gateways and hubs. 
The analysis of the changing distribution of vessel movements is only a first step towards a better understanding of Asian port cities as a whole. Further research shall concentrate on better classifying port cities based on more advanced statistical methods that would highlight, for instance, specific clusters of port cities sharing comparable evolutionary pathways. Another research direction would be to better link port dynamics with urban dynamics over the period under study, perhaps through immense efforts put on collecting urban indicators such as demographic size for cities. This would better highlight the relative importance of port activities compared with the rest of the urban economy, as port functions grow but also decline depending on local policies and strategies in various domains. Lastly, it was not assessed how Asian port cities have been connected through maritime flows and what is the architecture of such linkages, based on a more detailed view of the network designed by the overlap of vessel flows. Such findings would prove even more fruitful when put into a comparative perspective with other large regions of the world such as Europe and North America for instance, where larger cities and larger ports continue, more than ever, to concentrate the bulk of economic life.

\section{Acknowledgements}

The author wishes to thank Mrs. Liliane Lizzi at Géographie-Cités for her help with cartography as well as Prof. François Durand-Dastès at Paris I University for his useful comments on the results of this work. The research leading to these results has received funding from the European Research Council under the European Union's Seventh Framework Programme (FP/2007-2013) / ERC Grant Agreement n. [313847] "World Seastems" ${ }^{3}$.

\footnotetext{
${ }^{3}$ http://www.world-seastems.cnrs.fr
} 


\section{References}

Airriess, C.A. (2001a) 'Regional production, information-communication technology, and the developmental state: the rise of Singapore as a global container hub', Geoforum, 32: 23554.

Airriess, C.A. (2001b) 'The regionalization of Hutchison Port Holdings in Mainland China', Journal of Transport Geography, 9: 267-78.

Arasaratnam, S. (1992) 'Pre-colonial and early-colonial port towns', in Banga, I. (ed.) Ports and their Hinterlands in India (1700-1950), New Delhi: Manohar, 367-72.

Basu, D.K. (1985) The Rise and Growth of the Colonial Port Cities in Asia, Berkeley: Center for South and South East Asian Studies.

Broeze, F. (1989) Brides of the Sea: Port Cities of Asia From the 16th-20th Centuries, Honolulu: University of Hawaii Press.

Broeze, F. (1997) Gateways of Asia: Port Cities of Asia in the 13th-20th Centuries, London \& New York: Kegan Paul International.

Ducruet, C. (2012) 'Ports et routes maritimes dans le monde (1890-1925)', Mappemonde, 106: http://mappemonde.mgm.fr/num34/lieux/lieux12201.html

Ducruet, C. (2013) 'Mapping global urban interactions: maritime flows and port hierarchies since the late nineteenth century ', Globalisation and World Cities Research Bulletin, 429: http://www.lboro.ac.uk/gawc/rb/rb429.html

Ducruet, C., Lee, S.W. and Ng, A.K.Y. (2011) 'Port competition and network polarization at the East Asian maritime corridor', Territoire en Mouvement, 10: 60-74.

Ducruet, C., Carvalho, L. and Roussin, S. (2012) 'The flight of Icarus? Incheon's transformation from port gateway to global city', in Hall, P.V. and Hesse, M. (eds.) Cities, Regions, and Flows, Routledge, 149-69.

Gipouloux, F. (2009) La Méditerranée Asiatique, Paris: CNRS. 
Kidwai, A.H. (1989) 'Port cities in a national system of ports and cities: a geographical analysis of India in the 20th century', in Broeze, F. (ed.) Brides of the Sea: Port Cities of Asia From the 16th-20th Centuries, Honolulu: University of Hawaii Press, 207-22.

Lee, S.W., Song, D.W. and Ducruet, C. (2008) 'A tale of Asia's world ports: the spatial evolution in global hub port cities', Geoforum, 39: 372-85.

MacGee, T. (1967) The Southeast Asian City: A Social Geography of the Primate Cities, London: G. Bell \& Sons Ltd.

Murphey, R. (1989) 'On the evolution of the port city', in Broeze, F. (ed.) Brides of the Sea: Port Cities of Asia From the 16th-20th Centuries, Honolulu: University of Hawaii Press, $223-45$.

Ness, G.D. and Tanigawa, K. (1992) Population Dynamics and Port City Development: Comparative Analysis of Ten Asian Port Cities, Kobe: Asian Urban Information Center.

Ng, A.K.Y. and Ducruet, C. (2014) The changing tides of port geography (1950-2012)', Progress in Human Geography (forthcoming).

Okuno, S. (2000) 'Urban policies of some port cities in the Asia-Pacific corridor', in Chapman, G.P. (ed.) Urban Growth and Development in Asia, Ashgate, 426-39.

Taillard, C. (2004) Intégrations régionales en Asie orientale, Paris: Les Indes Savantes.

Tang, Q. (2009) 'Inter-port transshipment between Shanghai and Hankou in foreign trade: 1864-1930', Frontiers of History in China, 4: 632-52.

Wang, C. and Ducruet, C. (2013) 'Regional resilience and spatial cycles: long-term evolution of the Chinese port system (221BC-2010AD)', Tijdschrift voor Economische en Sociale Geografie. 104: 521-38.

\section{Appendix 1: Port geography papers on Asian port cities}


Airriess, C.A. (1989) 'The spatial spread of container transport in a developing regional economy: North Sumatra, Indonesia', Transportation Research Part A, 23: 453-61.

Airriess, C.A. (1991) 'Global economy and port morphology in Belawan, Indonesia', Geographical Review, 81: 183-96.

Boxer, B. (1962) 'Shipping movement and economic growth in Hong Kong, 1957-1958', Annals of the Association of American Geographers, 52: 321.

Bristow, R., Zhao, X. and Leung, T.P.S. (1995) 'Some consequences and impacts of port development - the Hong Kong case', Geojournal, 37: 525-36.

Chang, T.C., Huang, S. and Savage, V.R. (2004) 'On the waterfront: globalization and urbanization in Singapore', Urban Geography, 25: 413-36.

Chen, C.S. (1957) 'The port of Keelung', Tijdschrift voor Economische en Sociale Geografie, 48: 112-18.

Cheung, R.K., Tong, J.H. and Slack, B. (2003) 'The transition from freight consolidation to logistics: the case of Hong Kong', Journal of Transport Geography, 11: 245-53.

De Nie, H.J. (1960) 'The Indus, Karachi and its hinterland', Tijdschrift voor Economische en Sociale Geografie, 51: 266-73.

Dutt, A.K. (1971) 'Delineation of the hinterland of Calcutta port', The Professional Geographer, 23: 22-7.

Dwyer, D.J. (1963) 'The recent development of the port of Hong Kong', Geography, 48: $317-20$.

Frémont, A. and Ducruet, C. (2005) 'The emergence of a mega-port - from the global to the local: the case of Busan', Tijdschrift voor Economische en Sociale Geografie, 96: 421-32. Hanrath, R.E. (1960) 'Port development in Japan', Tijdschrift voor Economische en Sociale Geografie, 51: 75-6. 
Haynes, K.E., Hsing, Y.M. and Stough, R.R. (1997) 'Regional port dynamics in the global economy: the case of Kaohsiung, Taiwan', Maritime Policy and Management, 24: 93-113.

Hitch, M.A. (1935) 'The port of Tientsin and its problems', Geographical Review, 25: 36781.

Hughes, A.M. (1979) 'The future of gulf ports', Geography, 64: 54-6.

Jacobs, W. and Hall, P.V. (2007) 'What conditions supply chain strategies of ports? The case of Dubai', Geojournal, 68: 327-42.

Kosambi, M. and Brush, J.E. (1988) 'Three colonial port cities in India', Geographical Review, 78: 32-47.

Krug, P. (1964) 'The development of Odessa as a port and trading centre', Tijdschrift voor Economische en Sociale Geografie, 55: 134-35.

Lee, S.W. and Ducruet, C. (2009) 'Spatial globalization in Asia-Pacific hub port cities: a comparison of Hong Kong and Singapore', Urban Geography, 30: 162-84.

Lee, Y.L. (1962) 'The port towns of British Borneo', Australian Geographer, 8: 161-72.

Maxwell, I.S. (1957) 'The development of the ports of East Pakistan', Geography, 42: 61-6.

Murphey, R. (1963) 'Urbanization and the Western impact in East Asia: the treaty-port phenomenon', Annals of the Association of Americans Geographers, 53: 612.

Reischauer, E.O. (1940) 'Notes on Tang Dynasty sea routes', Harvard Journal of Asiatic Studies, 5: 142-64.

Robinson, R. (1984) 'Industrial strategies and port development in developing countries: the Asian case', Tijdschrift voor Economische en Sociale Geografie, 76: 133-43.

Robinson, R. and Chu, D. (1978) 'Containerization and the port of Hong Kong in the 1970s', Australian Geographer, 14: 98-111.

Slack, B. and Wang, J.J. (2002) 'The challenge of peripheral ports: an Asian perspective', Geojournal, 56: 159-66. 
Song, D.W. (2002) 'Regional container port competition and co-operation: the case of Hong Kong and South China', Journal of Transport Geography, 10: 99-110.

Tan, T.Y. (2007) 'Port cities and hinterlands: a comparative study of Singapore and Calcutta', Political Geography, 26: 851-65.

Todd, D. (1993) 'The interplay of trade, regional and technical factors in the evolution of a port system: the case of Taiwan', Geografiska Annaler B, 75: 3-18.

Todd, D. (1994) 'Changing technology, economic growth and port development: the transformation of Tianjin', Geoforum, 25: 285-303.

Todd, D. (1997) 'China's energy needs, coal transfers and the ports sector', Geoforum, 28: $39-53$.

Todd, D. and Hsueh, Y.C. (1990) 'New port developments and balanced regional growth: a Taiwan example', Geoforum, 21: 421-33.

Todd, D. and Zhang, L. (1993) 'Political and technical factors impinging on port operations: the case of Manchuria', Geojournal, 30: 441-54.

Tregear, T.R. (1954) 'Shih Hui Yao. A Chinese river port with a future', Geography, 39: $113-17$.

Uernstedt, F.L. (1966) 'Cebu: focus of Philippine inter-island trade', Economic Geography. Van Suylichem, A.P.G.M. (1968) 'Calcutta's new harbour as a magnet in the urbanisation process in Eastern India', Tijdschrift voor Economische en Sociale Geografie, 59: 326-34. Walker, A.R. (1989) 'Recessional and Gulf War impacts on port development and shipping in the Gulf States in the 1980's', Geojournal, 18: 273-84.

Wang, C. and Ducruet, C. (2012) 'New port development and global city making: emergence of the Shanghai-Yangshan multiayered gateway hub', Journal of Transport Geography, 25: 58-69. 
Wang, J.J. and Cheng, M.C. (2010) 'From a hub port city to a global supply chain management center: a case study of Hong Kong', Journal of Transport Geography, 18: 10415.

Wang, J.J. and Ng, A.K.Y. (2011) 'The geographical connectedness of Chinese seaports with foreland markets: a new trend?', Tijdschrift voor Economische en Sociale Geografie, 102: $188-204$.

Wang, J.J. and Olivier, D. (2006) 'Port-FEZ bundles as spaces of global articulation: the case of Tianjin, China', Environment and Planning A, 38: 1487-1503.

Wang, J.J. and Slack, B. (2000) 'The evolution of a regional container port system: the Pearl River Delta', Journal of Transport Geography, 8: 263-75.

Ward, M. (1961) 'Malayan fishing ports and their inland connections', Tijdschrift voor Economische en Sociale Geografie, 55: 113-42.

Ward, M. (1966) 'Major port hinterlands in Malaya', Tijdschrift voor Economische en Sociale Geografie, 57: 242-51.

Wiens, H.J. (1955) 'Riverine and coastal junks in China's commerce', Economic Geography, 31: $248-64$. 


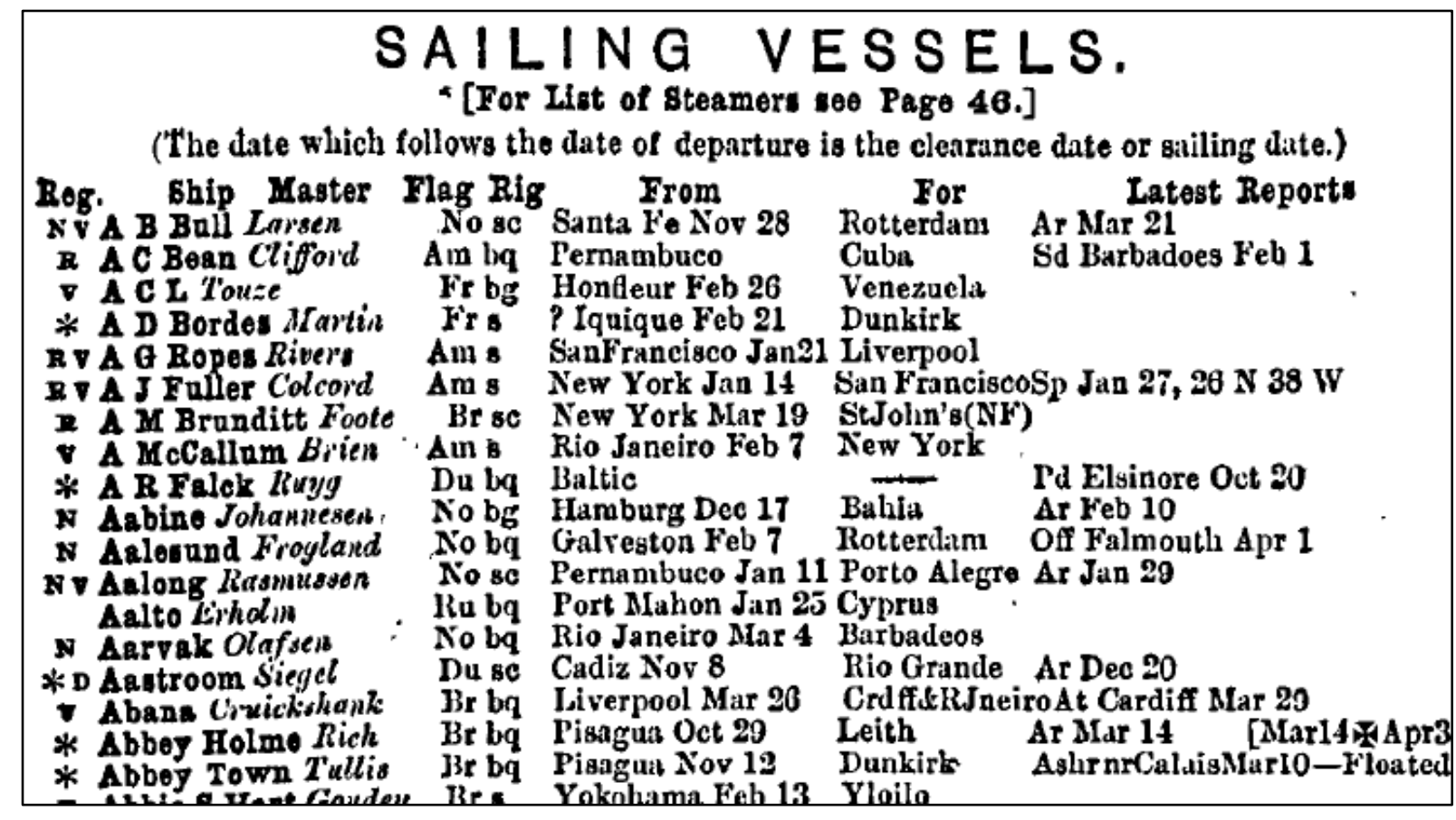

Figure 1. The Lloyd's Shipping Index in 1890

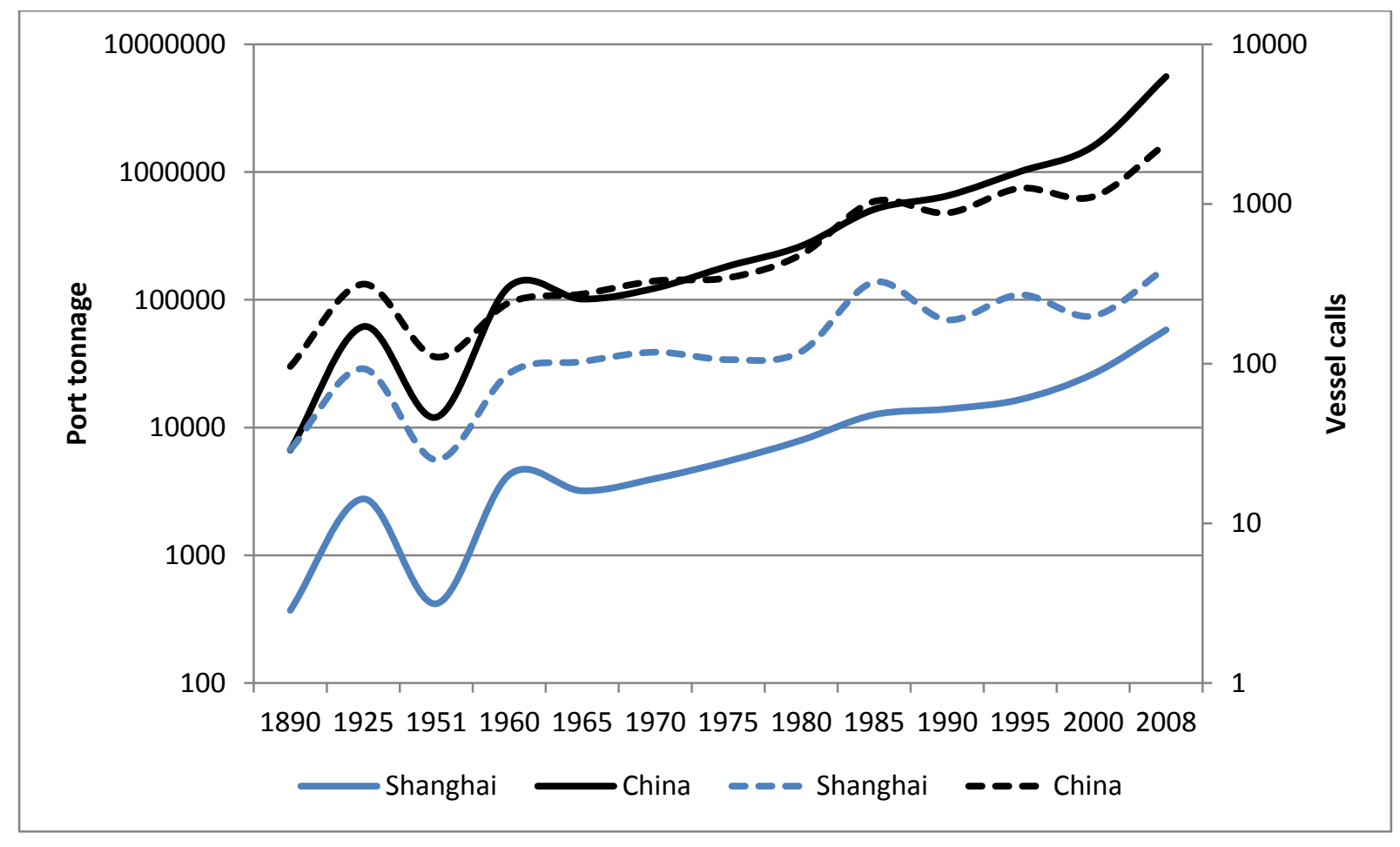

Figure 2. Global and local data source comparison based on the Chinese case, 1890-2008 


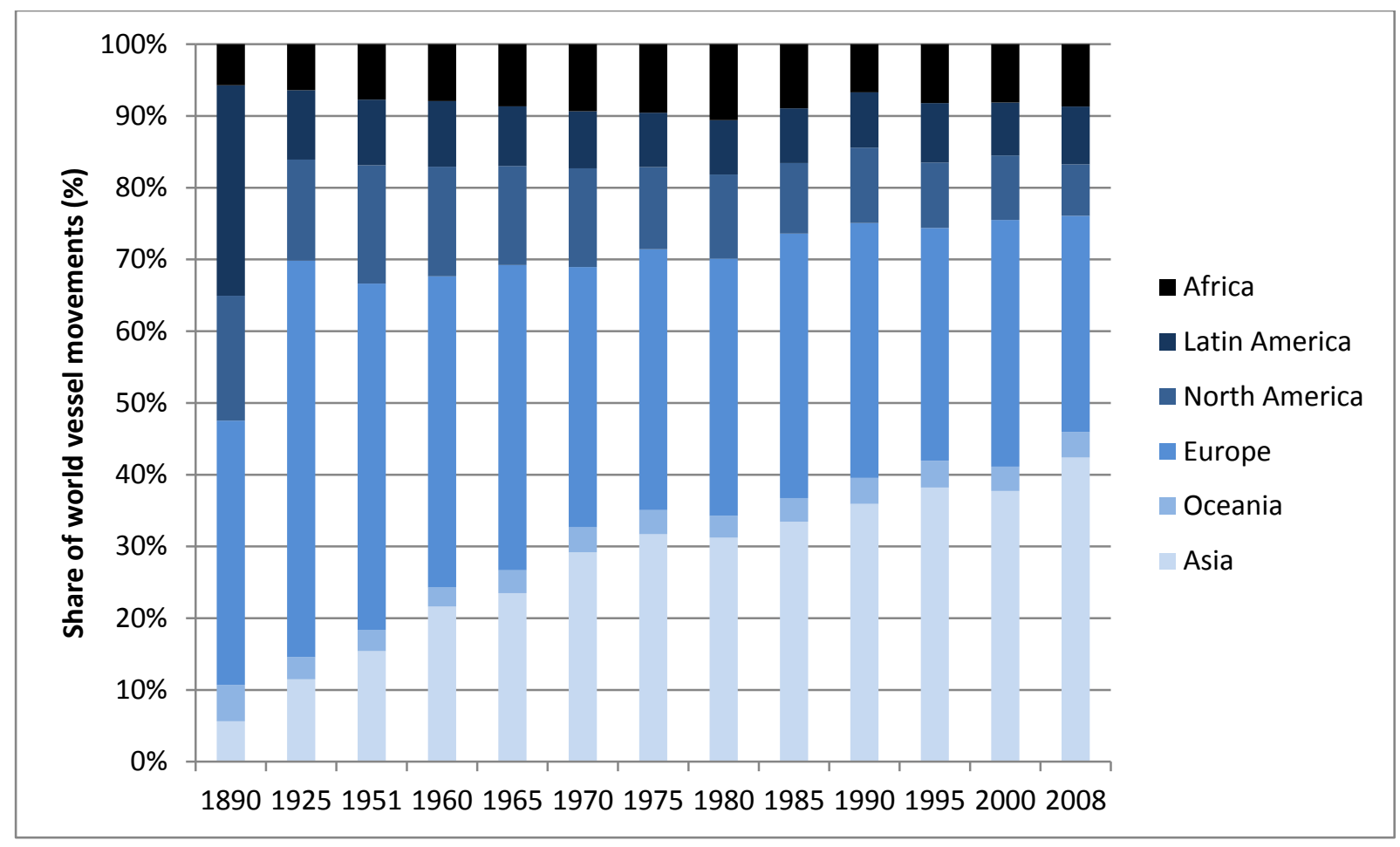

Figure 3. Regional distribution of world vessel movements, 1890-2008

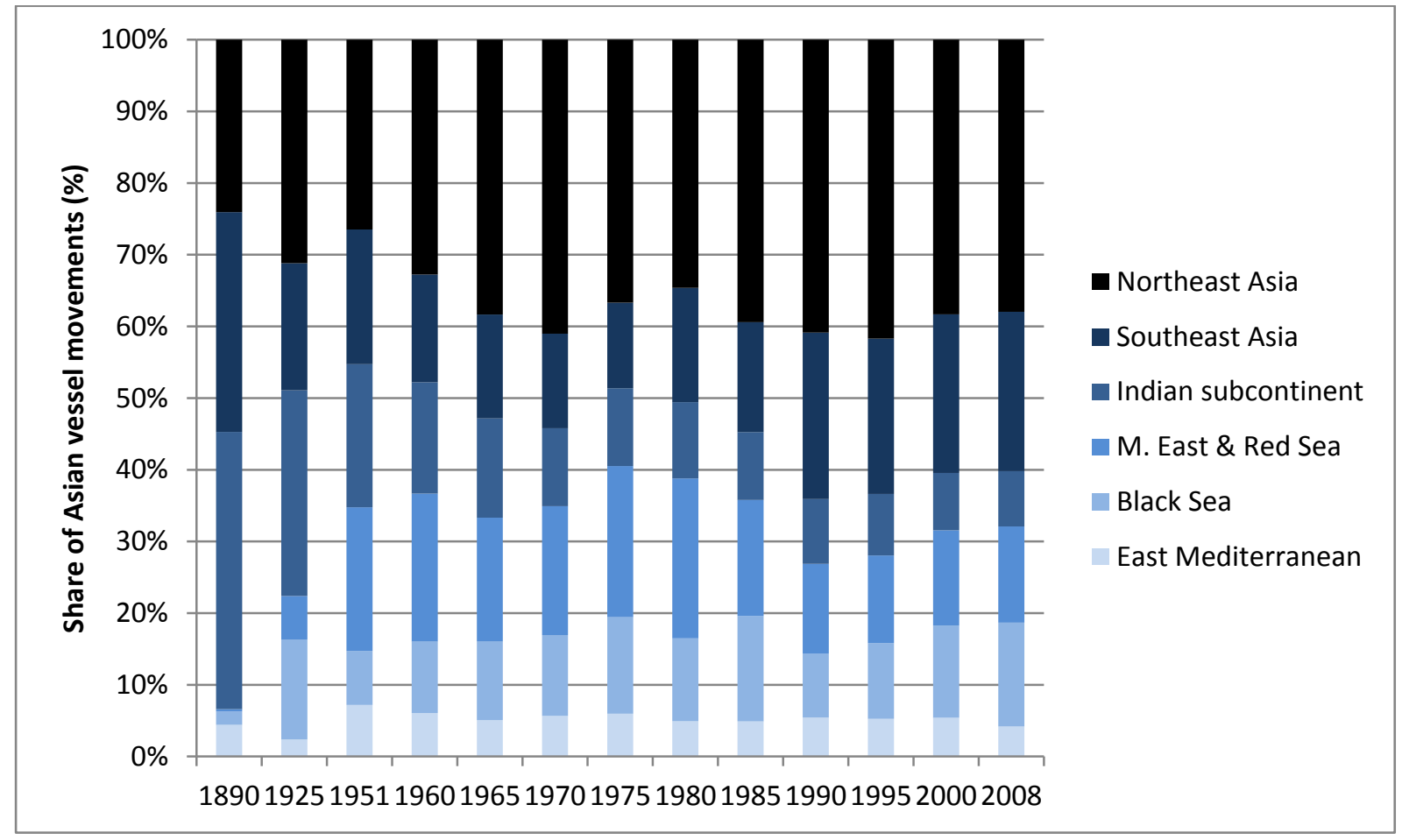

Figure 4. Regional distribution of vessel movements in Asia, 1890-2008 


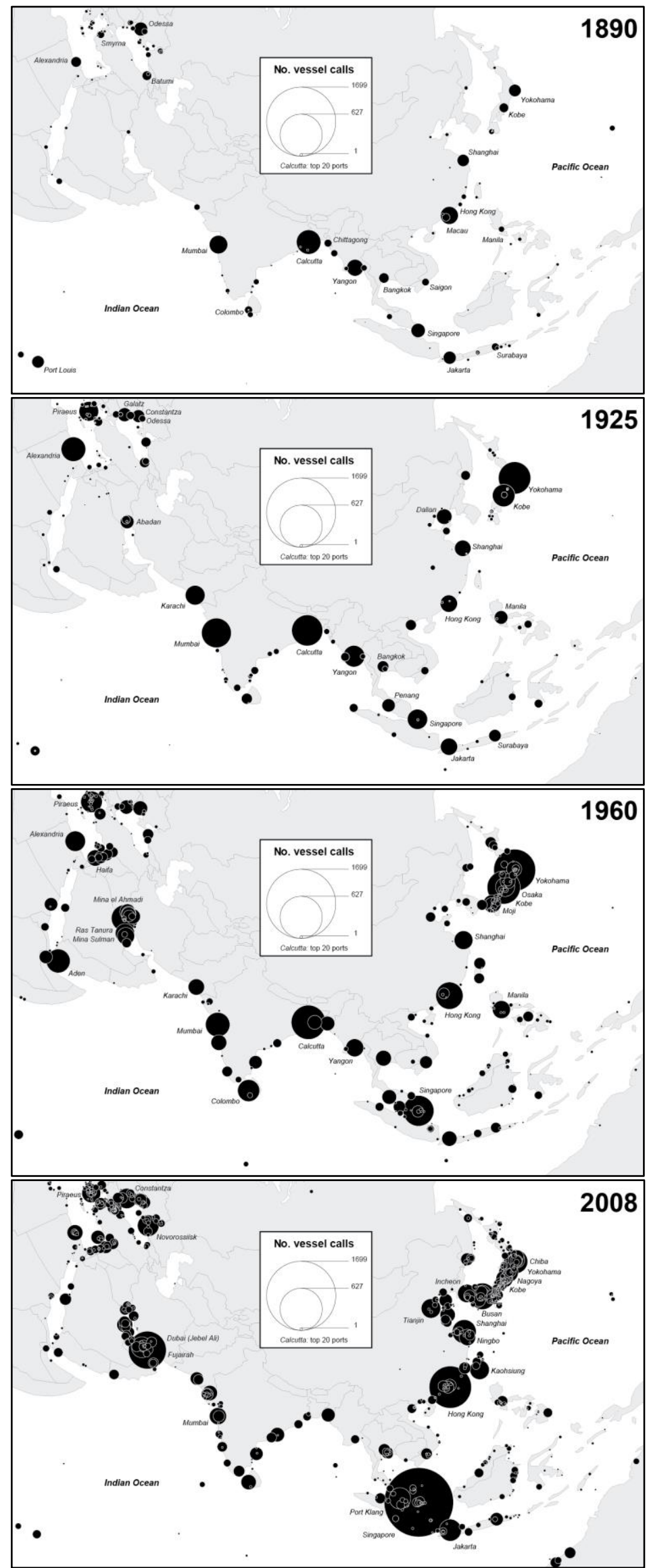

Figure 5. Traffic hierarchy of Asian port cities, 1890-2008 


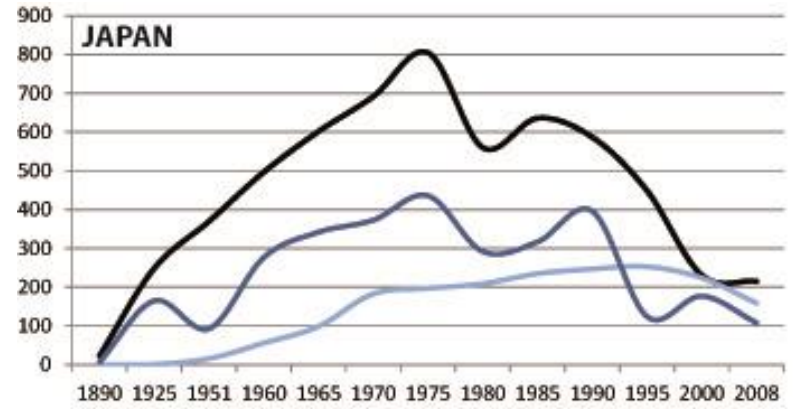

-Yokohama - Nagoya Kobe

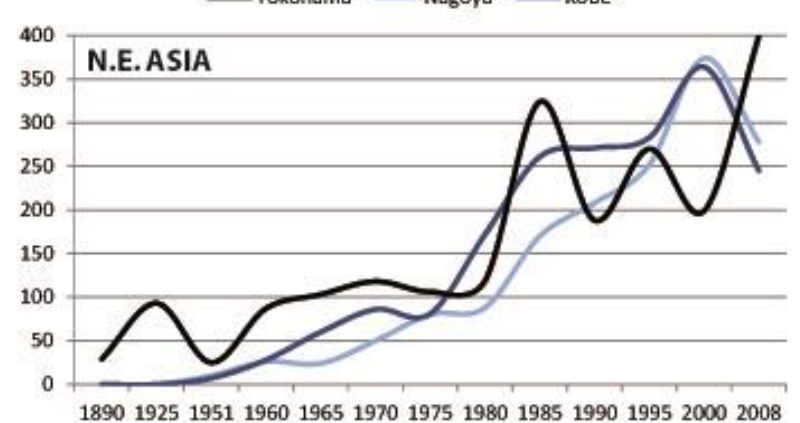

-Busan Kaohsiung - Shanghal

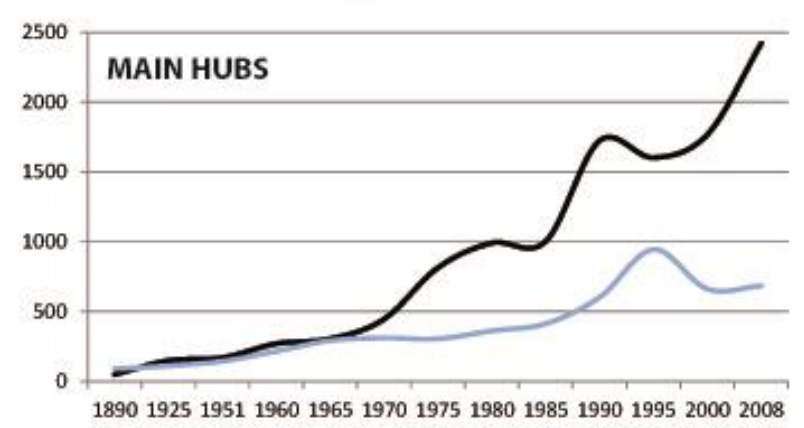

- Singapore Hong Kong

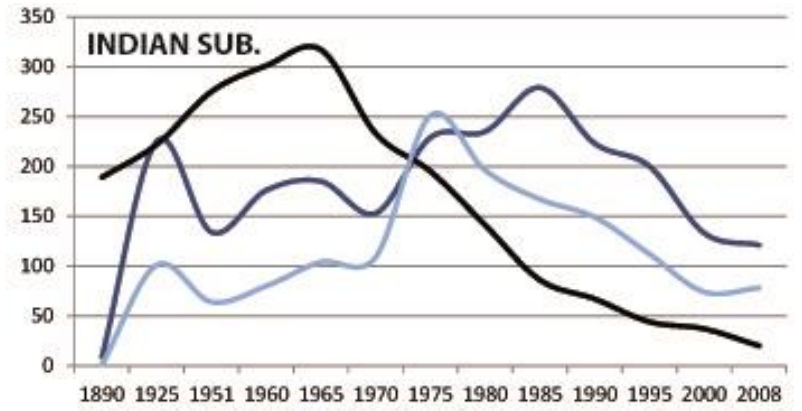

Mumbal -Kolkata Karachl

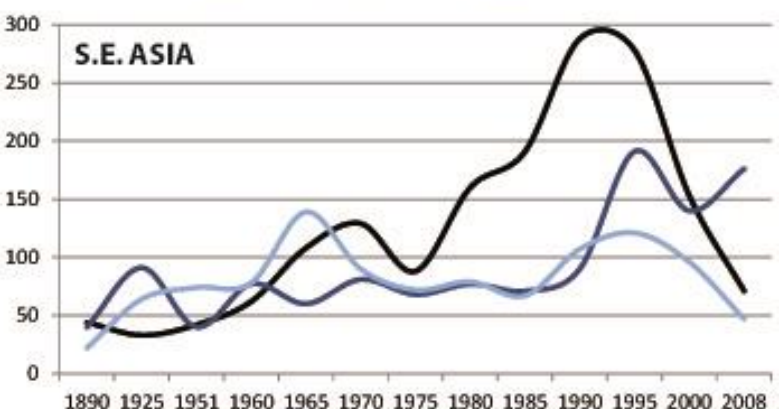

-Bangkok -Jakarta Manila

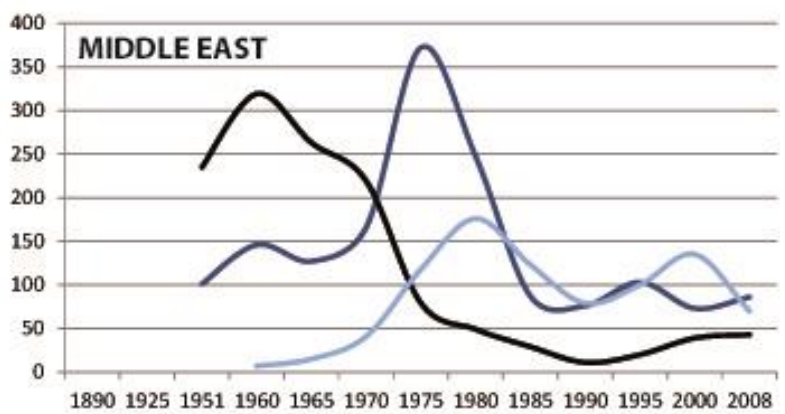

-Ras Tanura Mina al Ahmadi —Dubal

Figure 6. Port trajectories of selected Asian cities, 1890-2008 